\title{
EFFECTS OF POTASSIUM ON RAM SPERMATOZOA DURING CHILLING TO AND STORAGE AT $5^{\circ} \mathrm{C}$
}

\author{
T. O'SHEA AND R. G. WALES \\ Department of Veterinary Physiology, University of Sydney, \\ Sydney, N.S.W., Australia
}

(Received 1st Fanuary 1964)

\begin{abstract}
Summary. Potassium (16 to $64 \mathrm{~mm}$ ) adversely affected ram spermatozoa during cooling from 30 to $5^{\circ} \mathrm{C}$, while magnesium was beneficial. The effect of potassium was independent of the rate of chilling or the dilution of semen between 1 in 10 and 1 in 20, but it was decreased by increasing the sodium content of the diluent and was increased by the presence of phosphate. The addition of potassium after chilling did not affect subsequent motility.

High potassium levels during chilling were detrimental to washed ram spermatozoa. Low levels, on the other hand, helped to maintain the motility of washed cells during the period of storage. The addition of seminal plasma did not modify the effect of potassium on washed cells.
\end{abstract}

\section{INTRODUCTION}

A number of workers have confirmed that potassium (4 to $5 \mathrm{~mm}$ ) stimulates the motility of washed ram and bull spermatozoa incubated in vitro at $37^{\circ} \mathrm{C}$ (Lardy \& Phillips, 1943; White, 1953a, b, c; Blackshaw, 1953a, b). More recently potassium has been shown to increase the viability of washed and unwashed dog and fowl spermatozoa (Wales \& White, 1958a, b).

Despite the evidence of the importance of potassium for in-vitro survival at $37^{\circ} \mathrm{C}$, there is little mention of its effects on spermatozoa at low temperatures. Choong \& Wales (1963) found that the addition of $10 \mathrm{~mm}$ potassium to synthetic diluents did not affect the survival of bull spermatozoa deep frozen to $-79^{\circ} \mathrm{C}$ after 2 or $18 \mathrm{hr}$ equilibration. In other experiments, these workers found that 36 to $85 \mathrm{~mm}$ potassium at a $\mathrm{Na}: \mathrm{K}$ ratio of $2: 1$ depressed the revival of deep frozen bull spermatozoa (C. H. Choong \& R. G. Wales, unpublished data, 1963). Kampschmidt, Meyer \& Herman (1953), however, were not able to demonstrate any difference between potassium carbonate and sodium carbonate buffers with respect to the viability of bull spermatozoa stored at $5^{\circ} \mathrm{C} \mathrm{for} \mathrm{up} \mathrm{to}$ $240 \mathrm{hr}$ after cooling. Apart from these observations on bull spermatozoa, the effect of this cation during storage, either at $5^{\circ} \mathrm{C}$ or at sub-zero temperatures, has not received attention. In the present paper, the effect of potassium ions on ram spermatozoa has been studied during cooling to $5^{\circ} \mathrm{C}$ and storage at this temperature. 


\section{MATERIALS AND METHODS}

Semen was collected from rams after electrical stimulation with the bipolar rectal electrode (Blackshaw, 1954) and only apparently normal ejaculates with good initial motility were used. During collection and transport to the laboratory, ejaculates were protected from sudden temperature changes. Experiments were started as soon after collection as practicable and, in general, samples had begun to chill within 30 min of collection.

Unless otherwise indicated in the paper, the isotonic basic diluent $(\mathrm{pH} 7.0)$ contained $20 \mathrm{~mm}$ mono- and di-sodium phosphate buffer, $76 \mathrm{~mm}$ sodium chloride, $88 \mathrm{~mm}$ lactose, $3 \%$ casein and $1.1 \mathrm{~mm}$ fructose as substrate for the spermatozoa. Preliminary experiments showed that levels of fructose between 1 and $6 \mathrm{~mm}$ in the diluent caused no change in the potassium effect during chilling. When required, potassium and magnesium were added to the diluents as the chloride salts and sodium chloride content adjusted to keep the diluent isotonic. In some cases, where indicated, phosphate buffer was replaced by $20 \mathrm{~mm}$ veronal- $\mathrm{HCl}$ buffer $(\mathrm{pH} 7.0)$ or $20 \mathrm{~mm}$ trishydroxymethylaminomethane (tris) buffer ( $\mathrm{pH} \mathrm{7.0)}$.

For some studies, the spermatozoa were lightly washed. This was done by diluting the semen $1: 2$ with casein-free basic diluent, and centrifuging it at $2000 \mathrm{rev} / \mathrm{min}$ (about $400 \mathrm{~g}$ ) for $10 \mathrm{~min}$. The supernatant was replaced with an equal volume of diluent and the spermatozoa dispersed and recentrifuged. The second supernatant was removed and the volume was adjusted to that of the original semen.

In general, $0.2 \mathrm{ml}$ aliquots of each ejaculate were mixed with $1.8 \mathrm{ml}$ of diluent in a test tube at $30^{\circ} \mathrm{C}$ and the semen suspensions were cooled to $5^{\circ} \mathrm{C}$ by placing in a beaker containing water at $30^{\circ} \mathrm{C}$ and standing in a refrigerated cabinet. Where required, chilling rates could be modified, but cooling from 30 to $5^{\circ} \mathrm{C}$ normally occupied $3 \mathrm{hr}$.

After reaching $5^{\circ} \mathrm{C}$ the samples were stored in the refrigerated cabinet for $42 \mathrm{hr}$, surrounded by a water jacket to avoid sudden fluctuations in temperature. Immediately after reaching $5^{\circ} \mathrm{C}$, and 18 and $42 \mathrm{hr}$ later, aliquots (approx. 0.5 $\mathrm{ml}$ ) were removed from each chilled sample with a cooled pasteur pipette and incubated at $37^{\circ} \mathrm{C}$ for $10 \mathrm{~min}$ before the evaluation of motility. Samples were randomized and readings were made on a warm stage under the low power microscope at $\frac{1}{2} \mathrm{hr}$ intervals for $1 \frac{1}{2} \mathrm{hr}$. The activity of the spermatozoa was given a score between 4 and 0 at each reading (Emmens, 1947). Since quarter grades were frequently used, all scores were multiplied by four and the indices of motility were calculated by summing the observations $(\times 4)$ over the $1 \frac{1}{2} \mathrm{hr}$ period (Emmens, 1948).

All experiments were of a factorial design and the significance of the results has been assessed by analysis of variance. All main effects and their first-order interactions were isolated and tested for significance, but, in the summary form for the tables, only the first-order interactions which were significant have been presented separately, and non-significant first-order interactions have been combined.

In order to estimate the effects of treatments during the period at $5^{\circ} \mathrm{C}$, differences in motility at 0,18 and $42 \mathrm{hr}$ have been isolated and tested for signi- 
ficance. However, since the aliquots assessed at these times were all drawn from the same chilled sample, the effects of time trends and their interactions have been treated as within-sample variates and tested against the separate withinsample error. In the tables, the within-sample and the between-sample sources of variation are presented separately together with their separate error mean squares.

TABLE 1

MEAN MOTILITY INDICES OF RAM SPERMATOZOA COOLED AT VARYING RATES IN THE PRESENCE OF DIFFERENT CONCENTRATIONS OF POTASSIUM

\begin{tabular}{|c|c|c|c|c|c|c|c|c|c|c|c|c|}
\hline \multirow{3}{*}{$\begin{array}{l}\text { Potassium } \\
\text { conc. }(m M)\end{array}$} & \multicolumn{12}{|c|}{ Time of cooling } \\
\hline & \multicolumn{4}{|c|}{$15 \mathrm{~min}$} & \multicolumn{4}{|c|}{$1 \mathrm{hr}$} & \multicolumn{4}{|c|}{$3 \mathrm{hr}$} \\
\hline & $0 \mathrm{hr}$ & $18 \mathrm{hr}$ & $42 \mathrm{hr}$ & Total & $0 \mathrm{hr}$ & $18 \mathrm{hr}$ & $42 \mathrm{hr}$ & Total & $0 \mathrm{hr}$ & $18 \mathrm{hr}$ & $42 \mathrm{hr}$ & Total \\
\hline $\begin{array}{r}0 \\
4 \\
16 \\
64\end{array}$ & $\begin{array}{l}23 \\
22 \\
22 \\
20\end{array}$ & $\begin{array}{l}20 \\
21 \\
18 \\
16\end{array}$ & $\begin{array}{l}16 \\
15 \\
17 \\
10\end{array}$ & $\begin{array}{l}59 \\
58 \\
57 \\
46\end{array}$ & $\begin{array}{l}29 \\
27 \\
29 \\
26\end{array}$ & $\begin{array}{l}24 \\
25 \\
25 \\
20\end{array}$ & $\begin{array}{l}23 \\
20 \\
23 \\
18\end{array}$ & $\begin{array}{l}76 \\
72 \\
77 \\
64\end{array}$ & $\begin{array}{l}36 \\
36 \\
33 \\
32\end{array}$ & $\begin{array}{l}32 \\
30 \\
30 \\
26\end{array}$ & $\begin{array}{l}25 \\
27 \\
28 \\
22\end{array}$ & $\begin{array}{l}93 \\
93 \\
91 \\
80\end{array}$ \\
\hline Total & 87 & 75 & 58 & 220 & 111 & 94 & 84 & 289 & 137 & 118 & 103 & 358 \\
\hline
\end{tabular}

Summary of the analysis of variance

\begin{tabular}{l|c|c}
\hline \multicolumn{1}{c|}{ Source of variation } & Degrees of freedom & Variance ratios \\
\hline Between chilled samples & 3 & $32 \cdot 95^{* *}$ \\
A Effect of potassium & 2 & $344 \cdot 90^{* *}$ \\
B Effect of chilling rate & 3 & $59 \cdot 00^{* *}$ \\
C Ejaculate differences & 6 & $52 \cdot 97 * *$ \\
First order interactions & 15 & $1 \cdot 24$ \\
B $\times$ C & 18 & $4 \cdot 1$ \\
Other interactions & & \\
Between-sample error & 2 & $135 \cdot 49 * *$ \\
Within chilled samples & 6 & $9 \cdot 17$ \\
D Effect of sampling time & 10 & $1 \cdot 38$ \\
First-order interactions & 78 & $4 \cdot 7$ \\
D $\times$ C & & \\
Other interactions & & \\
Within-sample error & & \\
\hline
\end{tabular}

Each sample was evaluated at 0,18 and $42 \mathrm{hr}$ after reaching $5^{\circ} \mathrm{C}$ and values are the means for four ejaculates.

** $P<0.01$.

\section{RESULTS}

The results of the first experiment, together with the summary of the analysis of variance, are shown in Table 1. Four ejaculates of ram spermatozoa were cooled to $5^{\circ} \mathrm{C}$ at different rates in a potassium-free diluent and in diluents containing 4,16 and $64 \mathrm{~mm}$ potassium chloride. Rates of cooling were so arranged that 
samples cooled from 30 to $5^{\circ} \mathrm{C}$ in $3 \mathrm{hr}$ could be compared with those cooled in $1 \mathrm{hr}$ or in $15 \mathrm{~min}$. Samples that were cooled to $5^{\circ} \mathrm{C}$ over $3 \mathrm{hr}$ in a potassium-free diluent survived best. Survival began to decline with a potassium concentration of $16 \mathrm{~mm}$ and motility was very depressed when the diluent in which the

\section{TABLE 2}

RESPONSE OF GHILLED RAM SPERMATOZOA TO THE ADDITION OF POTASSIUM BEFORE AND AFTER GHILLING

\begin{tabular}{|c|c|c|c|c|c|c|c|c|c|}
\hline \multirow{2}{*}{\multicolumn{2}{|c|}{$\begin{array}{c}\text { Potassium } \\
\text { conc. }(m M)\end{array}$}} & \multicolumn{8}{|c|}{ Ratio semen: diluent during chilling } \\
\hline & & \multicolumn{4}{|c|}{$1: 20$} & \multicolumn{4}{|c|}{$1: 10$} \\
\hline $\begin{array}{c}\text { Pre- } \\
\text { chilling }\end{array}$ & $\begin{array}{c}\text { Post- } \\
\text { chilling }\end{array}$ & $0 \mathrm{hr}$ & $18 \mathrm{hr}$ & $42 h r$ & Total & $0 \mathrm{hr}$ & $18 \mathrm{hr}$ & $42 \mathrm{hr}$ & Total \\
\hline $\begin{array}{r}0 \\
16 \\
64\end{array}$ & $\begin{array}{r}0 \\
8 \\
32\end{array}$ & $\begin{array}{l}25 \\
23 \\
22\end{array}$ & $\begin{array}{l}19 \\
20 \\
15\end{array}$ & $\begin{array}{l}18 \\
19 \\
12\end{array}$ & $\begin{array}{l}62 \\
62 \\
49\end{array}$ & $\begin{array}{l}28 \\
27 \\
26\end{array}$ & $\begin{array}{l}23 \\
23 \\
20\end{array}$ & $\begin{array}{l}24 \\
24 \\
18\end{array}$ & $\begin{array}{l}75 \\
74 \\
64\end{array}$ \\
\hline $\begin{array}{l}0 \\
0 \\
0\end{array}$ & $\begin{array}{r}0 \\
8 \\
32\end{array}$ & $\begin{array}{l}25 \\
25 \\
25\end{array}$ & $\begin{array}{l}21 \\
21 \\
19\end{array}$ & $\begin{array}{l}19 \\
21 \\
19\end{array}$ & $\begin{array}{l}65 \\
67 \\
63\end{array}$ & $\begin{array}{l}29 \\
26 \\
26\end{array}$ & $\begin{array}{l}24 \\
23 \\
22\end{array}$ & $\begin{array}{l}25 \\
23 \\
24\end{array}$ & $\begin{array}{l}78 \\
72 \\
72\end{array}$ \\
\hline \multicolumn{2}{|c|}{ Total } & 145 & 115 & 108 & 368 & 162 & 135 & 138 & 435 \\
\hline
\end{tabular}

Summary of the analysis of variance

\begin{tabular}{l|c|c}
\hline \multicolumn{1}{c|}{ Source of variation } & Degrees of freedom & Variance ratio \\
\hline Between chilled samples & 2 & \\
A Effect of potassium & 1 & $19 \cdot 05^{* * *}$ \\
B Time of potassium addition & 1 & $16 \cdot 68^{* * *}$ \\
C Effect of semen dilution & 3 & $96 \cdot 17^{* * *}$ \\
D Ejaculate differences & 2 & $87 \cdot 44^{* *}$ \\
First-order interactions & 3 & $6 \cdot 74^{* *}$ \\
A $\times$ B & 12 & $5 \cdot 60^{* * *}$ \\
C $\times$ D interactions & 23 & $0 \cdot 63$ \\
Other inter & & \\
Between-sample error & 2 & $87 \cdot 76^{* *}$ \\
Within chilled samples & 2 & $3 \cdot 74^{*}$ \\
E Effect of sampling time & 6 & $10 \cdot 22^{* * *}$ \\
First-order interactions & 6 & $4 \cdot 5$ \\
E $\times$ C & 80 & \\
E $\times$ D & & \\
Other interactions & & \\
Within-sample error & & \\
\hline
\end{tabular}

Values are the mean motility indices for four ejcaulates evaluated at 0 , 18 and $42 \mathrm{hr}$ after chilling.

$$
* P<0.05 ; * * P<0.01 \text {. }
$$

spermatozoa were cooled contained $64 \mathrm{~mm}$ potassium. Rapid cooling was detrimental and to ensure good revival in all subsequent experiments, semen samples were chilled over a 3-hr period. Following cooling, however, the motility of the surviving cells declined at a similar rate during the next $42 \mathrm{hr}$ irrespective of the treatment during cooling. This indicated that potassium 
probably had a detrimental effect only during chilling. Therefore the next experiment was designed to determine whether potassium had an effect during the $42 \mathrm{hr}$ at $5^{\circ} \mathrm{C}$.

Aliquots of ram semen were mixed with four and nine volumes of a potassiumfree diluent and with similar quantities of diluents containing 16 and $64 \mathrm{~mm}$ potassium. After cooling to $5^{\circ} \mathrm{C}$, the samples were mixed with equal volumes of

\section{TABLE 3}

EFFECT OF VARYING CONCENTRATIONS OF SODIUM ON THE DETRIMENTAL EFFECTS OF POTASSIUM TO RAM SPERMATOZOA GHILLED TO $5^{\circ} \mathrm{c}$

\begin{tabular}{|c|c|c|c|c|c|c|c|c|c|c|c|c|}
\hline \multirow{3}{*}{$\begin{array}{l}\text { Final sodium } \\
\text { conc. }(m M)\end{array}$} & \multicolumn{12}{|c|}{ Potassium concentration ( $m M$ ) } \\
\hline & \multicolumn{4}{|c|}{0} & \multicolumn{4}{|c|}{12} & \multicolumn{4}{|c|}{36} \\
\hline & $0 \mathrm{hr}$ & $18 \mathrm{hr}$ & $42 \mathrm{hr}$ & Total & $0 \mathrm{hr}$ & $18 \mathrm{hr}$ & $42 h$ & Total & $0 \mathrm{hr}$ & $18 \mathrm{hr}$ & $42 \mathrm{hr}$ & Total \\
\hline $\begin{array}{r}40 \\
60 \\
100\end{array}$ & $\begin{array}{l}17 \\
15 \\
15\end{array}$ & $\begin{array}{l}16 \\
15 \\
16\end{array}$ & $\begin{array}{l}15 \\
16 \\
17\end{array}$ & $\begin{array}{l}48 \\
46 \\
48\end{array}$ & $\begin{array}{l}14 \\
15 \\
16\end{array}$ & $\begin{array}{l}13 \\
13 \\
15\end{array}$ & $\begin{array}{l}16 \\
14 \\
15\end{array}$ & $\begin{array}{l}43 \\
42 \\
46\end{array}$ & $\begin{array}{l}10 \\
12 \\
14\end{array}$ & $\begin{array}{r}9 \\
11 \\
10\end{array}$ & $\begin{array}{l}10 \\
12 \\
12\end{array}$ & $\begin{array}{l}29 \\
35 \\
36\end{array}$ \\
\hline Total & 47 & 47 & 48 & 142 & 45 & 41 & 45 & 131 & 36 & 30 & 34 & 100 \\
\hline
\end{tabular}

Summary of the analysis of variance

\begin{tabular}{l|c|c}
\hline \multicolumn{1}{c|}{ Source of variation } & Degrees of freedom & Variance ratio \\
\hline Between chilled samples & & \\
A Effect of potassium & 2 & $60 \cdot 93^{* *}$ \\
B Effect of sodium & 2 & $1 \cdot 32$ \\
C Ejaculate differences & 2 & $128 \cdot 30^{* * *}$ \\
First-order interactions & & \\
$\quad$ A $\times$ B & 1 & $6 \cdot 21^{*}$ \\
$\quad$ Linear $\times$ linear & 3 & $1 \cdot 05$ \\
$\quad$ Other & 8 & $1 \cdot 97$ \\
Other first-order interactions & 8 & $2 \cdot 8$ \\
Between-sample error & & \\
Within chilled samples & 2 & $5 \cdot 26^{* * *}$ \\
D Effect of sampling time & & $21 \cdot 67^{* * *}$ \\
First-order interactions & & $0 \cdot 61$ \\
$\quad$ D $\times$ C & & $3 \cdot 5$ \\
Other interactions & 8 & \\
Within-sample error & 40 & \\
\hline
\end{tabular}

Samples were examined at 0,18 and $42 \mathrm{hr}$ after reaching $5^{\circ} \mathrm{C}$ and mean motility indices for three ejaculates are given.

$* P<0.05$; $* P<0.01$.

precooled potassium-free diluent to give a final potassium concentration of 8 or $32 \mathrm{~mm}$. The motility of these samples was then compared with others similarly diluted with the potassium-free diluent, chilled to $5^{\circ} \mathrm{C}$ and then mixed with equal volumes of precooled potassium-containing diluents to give final concentrations of 8 and $32 \mathrm{~mm}$ potassium. Thus, samples cooled in the presence of potassium could be compared with samples in which potassium was added after 
reaching $5^{\circ} \mathrm{C}$. The results of four ejaculates, together with the summary of the analysis of variance, are shown in Table 2. Even at the high concentrations of semen used, the effects of dilution were evident. The more concentrated samples survived chilling better and showed a slower decline in motility during the $\mathbf{4 2}$ $\mathrm{hr}$ storage at $5^{\circ} \mathrm{C}$. Motility was depressed in samples where large amounts of

TABLE 4

EFFECTS OF VARYING CONCENTRATIONS OF PHOSPHATE BUFFER (pH 7.0) ON THE DEPRESSION CAUSED BY POTASSIUM DURING CHILLING RAM SPERMATOZOA

\begin{tabular}{|c|c|c|c|c|c|c|c|c|c|c|c|c|}
\hline \multirow{3}{*}{$\begin{array}{c}\text { Phosphate } \\
\text { conc. }(m M)\end{array}$} & \multicolumn{12}{|c|}{ Potassium concentration $(m M)$} \\
\hline & \multicolumn{4}{|c|}{0} & \multicolumn{4}{|c|}{16} & \multicolumn{4}{|c|}{64} \\
\hline & $0 \mathrm{hr}$ & $18 \mathrm{hr}$ & $42 \mathrm{hr}$ & Total & $0 \mathrm{hr}$ & $18 \mathrm{hr}$ & $42 \mathrm{hr}$ & Total & $0 \mathrm{hr}$ & $18 \mathrm{hr}$ & $42 h r$ & Total \\
\hline $\begin{array}{l}10 \\
20 \\
40\end{array}$ & $\begin{array}{l}25 \\
27 \\
28\end{array}$ & $\begin{array}{l}25 \\
23 \\
25\end{array}$ & $\begin{array}{l}22 \\
24 \\
23\end{array}$ & $\begin{array}{l}72 \\
74 \\
76\end{array}$ & $\begin{array}{l}25 \\
25 \\
27\end{array}$ & $\begin{array}{l}22 \\
19 \\
21\end{array}$ & $\begin{array}{l}22 \\
21 \\
20\end{array}$ & $\begin{array}{l}69 \\
65 \\
68\end{array}$ & $\begin{array}{l}22 \\
21 \\
17\end{array}$ & $\begin{array}{l}18 \\
15 \\
13\end{array}$ & $\begin{array}{r}21 \\
16 \\
9\end{array}$ & $\begin{array}{l}61 \\
52 \\
39\end{array}$ \\
\hline Total & 80 & 73 & 69 & 222 & 77 & 62 & 63 & 202 & 60 & 46 & 46 & 152 \\
\hline
\end{tabular}

Summary of the analysis of variance

\begin{tabular}{l|c|c}
\hline \multicolumn{1}{c|}{ Source of variation } & Degrees of freedom & Variance ratio \\
\hline Between chilled samples & & \\
A Effect of potassium & 2 & $92 \cdot 93^{* *}$ \\
B Effect of phosphate & 2 & $8 \cdot 00^{* *}$ \\
C Ejaculate differences & 3 & $202 \cdot 18^{* *}$ \\
First-order interactions & & \\
A $\times$ B & 1 & $33 \cdot 06^{* * *}$ \\
$\quad$ Linear $\times$ linear & 3 & $2 \cdot 80$ \\
Other & 6 & $14 \cdot 54 * *$ \\
A $\times$ C & 6 & $1 \cdot 25$ \\
B $\times$ C & 12 & $6 \cdot 3$ \\
Between-sample error & & \\
Within chilled samples & 2 & $50 \cdot 61 * *$ \\
D Effect of sampling time & 4 & $1 \cdot 53$ \\
First-order interactions & 4 & $4 \cdot 39 * *$ \\
D $\times$ A & 6 & $6 \cdot 47 * *$ \\
D $\times$ B & 56 & $4 \cdot 4$ \\
D $\times$ C & & \\
Within-sample error & & \\
\hline
\end{tabular}

Mean motility indices for four ejaculates evaluated at 0,18 and $42 \mathrm{hr}$ after cooling are given in the table.

*** $P<0.01$.

potassium were present during chilling, but was not affected by its addition after reaching $5^{\circ} \mathrm{C}$.

In subsequent experiments, other components of diluents were scanned for their possible interactions with potassium during cooling to $5^{\circ} \mathrm{C}$. The effect of sodium concentration on the depression caused by potassium during chilling is shown in Table 3 . Sodium chloride $(18,36$ and $72 \mathrm{~mm})$ was included in 
potassium-free diluents and in diluents containing 12 and $36 \mathrm{~mm}$ potassium chloride. The diluents were buffered with mono- and di-sodium phosphates and isotonicity was maintained by varying the lactose content. The total sodium content of these diluents was approximately 40,60 and $100 \mathrm{~mm}$ respectively. There was a significant interaction between potassium and sodium in the analysis of

\section{TABLE 5}

MEAN MOTILITY INDICES OF FOUR RAM EJAGULATES AFTER GOOLING TO $5^{\circ} \mathrm{c}$ IN THE PRESENCE OF VARYING CONCENTRATIONS OF POTASSIUM AND TRIS BUFFER (pH 7.0)

\begin{tabular}{|c|c|c|c|c|c|c|c|c|c|c|c|c|}
\hline \multirow{3}{*}{$\begin{array}{c}\text { Potassium } \\
\text { conc. }(m M)\end{array}$} & \multicolumn{12}{|c|}{ Concentration of tris buffer ( $m M$ ) } \\
\hline & \multicolumn{4}{|c|}{0} & \multicolumn{4}{|c|}{10} & \multicolumn{4}{|c|}{40} \\
\hline & $0 \mathrm{hr}$ & $18 \mathrm{hr}$ & $42 \mathrm{hr}$ & Total & $0 h r$ & $18 \mathrm{hr}$ & $42 \mathrm{hr}$ & Total & $0 \mathrm{hr}$ & $18 \mathrm{hr}$ & $42 \mathrm{hr}$ & Total \\
\hline $\begin{array}{r}0 \\
16 \\
64\end{array}$ & $\begin{array}{l}35 \\
40 \\
27\end{array}$ & $\begin{array}{l}31 \\
29 \\
26\end{array}$ & $\begin{array}{l}34 \\
25 \\
21\end{array}$ & $\begin{array}{r}100 \\
94 \\
74\end{array}$ & $\begin{array}{l}31 \\
28 \\
24\end{array}$ & $\begin{array}{l}28 \\
24 \\
24\end{array}$ & $\begin{array}{l}26 \\
25 \\
21\end{array}$ & $\begin{array}{l}85 \\
77 \\
69\end{array}$ & $\begin{array}{l}26 \\
25 \\
26\end{array}$ & $\begin{array}{l}25 \\
24 \\
24\end{array}$ & $\begin{array}{l}25 \\
23 \\
23\end{array}$ & $\begin{array}{l}76 \\
72 \\
73\end{array}$ \\
\hline Total & 102 & 86 & 80 & 268 & 83 & 76 & 72 & 231 & 77 & 73 & 71 & 221 \\
\hline
\end{tabular}

Summary of the analysis of variance

\begin{tabular}{l|c|c}
\hline \multicolumn{1}{c|}{ Source of variation } & Degrees of freedom & Variance ratio \\
\hline Between chilled samples & & \\
A Effect of potassium & 2 & $17 \cdot 14^{* *}$ \\
B Effect of tris & 3 & $21 \cdot 23^{* *}$ \\
C Ejaculate differences & $6 \cdot 95^{* *}$ \\
First-order interactions & 4 & $3 \cdot 86^{*}$ \\
A $\times$ B & 6 & $2 \cdot 23$ \\
A $\times$ C & 6 & $8 \cdot 84^{* *}$ \\
B $\times$ C & 12 & $11 \cdot 1$ \\
Between-sample error & & \\
Within chilled samples & 2 & $10 \cdot 25^{* *}$ \\
D Effect of sampling time & 6 & $4 \cdot 03^{* * *}$ \\
First-order interactions & $1 \cdot 27$ \\
D $\times$ C & 8 & $20 \cdot 7$ \\
Other interactions & 56 & \\
Within-sample error & & \\
\hline
\end{tabular}

All diluents contained $20 \mathrm{~mm}$ phosphate buffer $(\mathrm{pH} \mathrm{7.0)}$ and motility was estimated at 0,18 and $42 \mathrm{hr}$ after chilling.

$$
* P<0.05 ; \text { ** } P<0.01 \text {. }
$$

variance. As the sodium content and the $\mathrm{Na}: \mathrm{K}$ ratio of the diluent increased, the depression caused by high potassium decreased.

Phosphate at 10,20 and $40 \mathrm{~mm}$ and potassium at 0,16 and $64 \mathrm{~mm}$ were studied in all combinations and the results, together with the summary of the analysis of variance, are shown in Table 4. Increase in phosphate concentration when potassium was absent improved motility slightly. There was, however, an interaction between potassium and phosphate and the detrimental effect of potassium during cooling was greatest in the presence of $40 \mathrm{~mm}$ phosphate. In 
addition, during the period of storage, motility was not maintained as well when both high potassium and high phosphate were included in the diluent.

In further experiments there was no significant effect of 4,16 or $64 \mathrm{~mm}$ potassium during chilling when phosphate buffer in the diluent was replaced by tris buffer. On the other hand, the effect of potassium occurred when veronal

TABLE 6

EFFECTS OF POTASSIUM AND MAGNESIUM ON THE RESPONSE OF WASHED AND UNWASHED RAM SPERMATOZOA TO GHILLING

\begin{tabular}{|c|c|c|c|c|c|c|c|c|c|}
\hline \multirow{3}{*}{ Treatment } & \multirow{3}{*}{$\begin{array}{c}\text { Potassium } \\
\text { conc. }(m M)\end{array}$} & \multicolumn{8}{|c|}{ Magnesium concentration $(m M)$} \\
\hline & & \multicolumn{4}{|c|}{0} & \multicolumn{4}{|c|}{11} \\
\hline & & $0 \mathrm{hr}$ & $18 \mathrm{hr}$ & $42 \mathrm{hr}$ & Total & $0 \mathrm{hr}$ & $18 \mathrm{hr}$ & $42 \mathrm{hr}$ & Total \\
\hline Unwashed & $\begin{array}{r}0 \\
16\end{array}$ & $\begin{array}{l}17 \\
16\end{array}$ & $\begin{array}{l}17 \\
14\end{array}$ & $\begin{array}{l}16 \\
14\end{array}$ & $\begin{array}{l}50 \\
44\end{array}$ & $\begin{array}{l}18 \\
17\end{array}$ & $\begin{array}{l}16 \\
18\end{array}$ & $\begin{array}{l}18 \\
17\end{array}$ & $\begin{array}{l}52 \\
52\end{array}$ \\
\hline Washed & $\begin{array}{r}0 \\
16\end{array}$ & $\begin{array}{l}12 \\
11\end{array}$ & $\begin{array}{l}9 \\
9\end{array}$ & $\begin{array}{r}6 \\
11\end{array}$ & $\begin{array}{l}27 \\
31\end{array}$ & $\begin{array}{l}14 \\
13\end{array}$ & $\begin{array}{l}12 \\
12\end{array}$ & $\begin{array}{r}7 \\
12\end{array}$ & $\begin{array}{l}33 \\
37\end{array}$ \\
\hline
\end{tabular}

Summary of analysis of variance

\begin{tabular}{|c|c|c|}
\hline Source of variation & Degrees of freedom & Variance ratio \\
\hline $\begin{array}{l}\text { Between chilled samples } \\
\text { A Effect of potassium } \\
\text { B Effect of magnesium } \\
\text { C. Washing effect } \\
\text { D. Ejaculate differences }\end{array}$ & $\begin{array}{l}1 \\
1 \\
1 \\
3\end{array}$ & $\begin{array}{c}0 \cdot 23 \\
25 \cdot 50 * * \\
267 \cdot 42 * * \\
113 \cdot 55^{* * *}\end{array}$ \\
\hline $\begin{array}{l}\text { First-order interactions } \\
\quad \mathrm{A} \times \mathrm{G} \\
\mathrm{G} \times \mathrm{D} \\
\text { Other interactions } \\
\text { Between-sample error }\end{array}$ & $\begin{array}{r}1 \\
3 \\
8 \\
13\end{array}$ & $\begin{array}{l}15 \cdot 75 * * \\
22 \cdot 89 * * \\
0 \cdot 59 \\
2 \cdot 9\end{array}$ \\
\hline $\begin{array}{l}\text { Within chilled samples } \\
\text { E Effect of sampling time }\end{array}$ & 2 & $11 \cdot 79 * *$ \\
\hline $\begin{array}{l}\mathrm{E} \times \mathrm{A} \\
\mathrm{E} \times \mathrm{C} \\
\text { Other first-order interactions } \\
\mathrm{E} \times \mathrm{A} \times \mathrm{C} \\
\text { Other second-order interactions } \\
\text { Within-sample error }\end{array}$ & $\begin{array}{r}2 \\
2 \\
8 \\
2 \\
22 \\
26\end{array}$ & $\begin{array}{l}4 \cdot 56^{*} \\
5 \cdot 06^{*} \\
2 \cdot 16 \\
7 \cdot 53^{* *} \\
0 \cdot 45 \\
3 \cdot 5\end{array}$ \\
\hline
\end{tabular}

Mean motility indices for four ejaculates examined at 0,18 and $42 \mathrm{hr}$ after reaching $5^{\circ} \mathrm{C}$ are given.

$$
\text { * } P<0.05 ; \quad * * P<0.01 \text {. }
$$

buffer was used to replace phosphate. An experiment was designed to see if tris would change the effect of potassium when phosphate was present in the diluent. Tris ( $\mathrm{pH} \mathrm{7.0)}$ was added to a potassium-free diluent containing $20 \mathrm{~mm}$ phosphate and the effect of these diluents during chilling was compared with those of similar diluents containing 16 or $64 \mathrm{~mm}$ potassium. The results for four ejaculates, together with the summary of the analysis of variance, are shown in 
Table 5. Both tris and potassium were found to depress motility of chilled samples, but the effect of the tris varied from ejaculate to ejaculate. At high potassium levels the effects of tris and potassium were less than would be expected from the sum of their separate effects and high potassium had a similar effect in the absence of tris as in its presence.

The effects of washing on the response of ram spermatozoa to chilling in the presence of low levels of potassium and magnesium are shown in Table 6.

TABLE 7

MOTILITY OF WASHED RAM SPERMATOZOA AFTER THE ADDITION OF 10\% SEMINAL PLASMA OR $10 \%$ DiALYSED SEMINAL PLASMA TO POTASSIUM-FREE AND POTASSIUMCONTAINING DILUENTS

\begin{tabular}{|c|c|c|c|c|c|c|c|c|c|c|c|c|}
\hline \multirow{3}{*}{$\begin{array}{l}\text { Potassium } \\
\text { conc. }(m M)\end{array}$} & \multicolumn{12}{|c|}{ Additives after washing } \\
\hline & \multicolumn{4}{|c|}{$\mathcal{N i l}$ (control) } & \multicolumn{4}{|c|}{ Seminal plasma } & \multicolumn{4}{|c|}{ Dialysed seminal plasma } \\
\hline & $0 \mathrm{hr}$ & $18 \mathrm{hr}$ & $42 h r$ & Total & $0 \mathrm{hr}$ & $18 \mathrm{hr}$ & $42 h r$ & Total & $0 \mathrm{hr}$ & $18 \mathrm{hr}$ & $42 h r$ & Total \\
\hline $\begin{array}{r}0 \\
64\end{array}$ & $\begin{array}{l}23 \\
16\end{array}$ & $\begin{array}{l}21 \\
16\end{array}$ & $\begin{array}{l}24 \\
18\end{array}$ & $\begin{array}{l}68 \\
50\end{array}$ & $\begin{array}{l}29 \\
24\end{array}$ & $\begin{array}{l}24 \\
17\end{array}$ & $\begin{array}{l}27 \\
22\end{array}$ & $\begin{array}{l}80 \\
63\end{array}$ & $\begin{array}{l}26 \\
21\end{array}$ & $\begin{array}{l}26 \\
18\end{array}$ & $\begin{array}{l}27 \\
22\end{array}$ & $\begin{array}{l}79 \\
61\end{array}$ \\
\hline
\end{tabular}

Summary of the analysis of variance

\begin{tabular}{l|c|c}
\hline \multicolumn{1}{c|}{ Source of variation } & Degrees of freedom & Variance ratio \\
\cline { 2 - 3 } Between chilled samples & 1 & $208 \cdot 15^{* * *}$ \\
A Effect of potassium & 1 & $43 \cdot 31 * *$ \\
B Effect of additives & 1 & $0 \cdot 66$ \\
$\quad$ (i) Control versus plasma & 3 & $14 \cdot 60^{* * *}$ \\
(ii) Effect of dialysis & 3 & $11 \cdot 52^{* * *}$ \\
C Ejaculate differences & 8 & $2 \cdot 77$ \\
First-order interactions & 6 & $4 \cdot 8$ \\
A C C & & \\
Other interactions & & $16 \cdot 65^{* * *}$ \\
Between-sample error & 2 & $1 \cdot 74$ \\
Within chilled samples & 12 & $5 \cdot 3$ \\
D Effect of sampling time & 34 & \\
First-order interactions & & \\
Within-sample error & & \\
\hline
\end{tabular}

Mean values for four ejaculates examined at 0,18 and $42 \mathrm{hr}$ after chilling are given.

$$
\text { ** } P<0.01 \text {. }
$$

Washed spermatozoa were more severely depressed by chilling than were unwashed cells. Magnesium (11 mM) was beneficial both to washed and unwashed spermatozoa. Potassium, on the other hand, had a differential effect and, although it slightly depressed the motility of unwashed spermatozoa, it stimulated the motility of washed cells. The beneficial effect of potassium to washed cells was due to the maintenance of motility during the period of storage rather than to initial stimulation. The motility of washed cells immediately after chilling in the presence of potassium was lower than that of washed cells chilled 
in a potassium-free diluent. The reverse was true, however, after $42 \mathrm{hr}$, and the motility of cells was much lower in potassium-free than in potassium-containing diluents.

The effect of chilling on washed ram spermatozoa in the presence of $64 \mathrm{~mm}$ potassium is shown in Table 7. Seminal plasma $(10 \% \mathrm{v} / \mathrm{v})$ and dialysed seminal plasma $(10 \% \mathrm{v} / \mathrm{v})$ were added to the diluents before chilling and both were found to have beneficial effects on the chilled cells. The presence of $64 \mathrm{~mm}$ potassium in the diluent during chilling severely depressed motility. The high potassium level did not have a beneficial effect during the period at $5^{\circ} \mathrm{G}$ and the decline in motility of spermatozoa in potassium-containing diluents was similar to that in potassium-free diluents.

\section{DISCUSSION}

The results clearly show that potassium ions are detrimental to ram spermatozoa during chilling from 30 to $5^{\circ} \mathrm{C}$. In no experiment was there interaction between potassium concentration and the time at which unwashed spermatozoa were examined after reaching $5^{\circ} \mathrm{C}$. Thus it would seem that the adverse effect of potassium is confined to the chilling period and that after the spermatozoa reach $5^{\circ} \mathrm{C}$, potassium no longer exerts a detrimental effect. Thus potassium had no effect on motility when added after the spermatozoa reached $5^{\circ} \mathrm{C}$. In fact, with washed spermatozoa the presence of $16 \mathrm{~mm}$ potassium during chilling and storage helped to maintain motility during storage even though its presence during chilling decreased motility.

High levels of potassium have been reported to be slightly toxic to mammalian spermatozoa (White, 1953c; Wales \& White, 1958a, b). However, Salisbury \& Lodge (1962) maintain that the inhibition caused by high levels of potassium is due to changes in the $\mathrm{Na}: \mathrm{K}$ ratio rather than in potassium content. In the present studies, the effect of high potassium ( $36 \mathrm{~mm}$ ) during chilling was modified by the presence of sodium and was greatest when the $\mathrm{Na}: \mathrm{K}$ ratio was low $(1: 1)$, but was still evident with $\mathrm{Na}: \mathrm{K}$ ratios as high as $3: 1$. It would not seem, therefore, that $\mathrm{Na}: \mathrm{K}$ ratio is the only or most important factor modifying the effects of potassium during chilling. For example, the presence of phosphate increased the detrimental effects of $64 \mathrm{~mm}$ potassium even when the $\mathrm{Na}: \mathrm{K}$ ratio remained unchanged.

Tris buffer has been shown to penetrate human red-cell membranes (Omachi, Macey \& Waldeck, 1961). Amines also competitively interfere with the uptake of potassium by bacteria (Macleod \& Onofrey, 1954), while in other organisms it is implied that tris might interfere with organic metabolites. In the experiments reported here, potassium in the presence of $20 \mathrm{~mm}$ tris buffer did not significantly affect ram spermatozoa during chilling. When $20 \mathrm{~mm}$ phosphate was added, however, both tris and potassium were harmful during chilling, but their effects were not additive. From these experiments with tris it might be argued that high intracellular potassium levels during chilling are responsible for the adverse effects caused by the inclusion of potassium in the diluent. As in bacteria, tris possibly decreases potassium uptake by spermatozoa and so decreases the adverse effect of this cation during chilling. The situation is further 
complicated by the addition of phosphate which itself increases the effects of potassium. Even under these circumstances tris and potassium in combination caused changes less than one might expect from the sum of their separate effects.

Cell membrane changes probably account for the irreversible damage caused by sudden cooling of spermatozoa to $0^{\circ} \mathrm{C}$ known as 'cold shock'. The phenomenon is accompanied by loss of ions from the cell (Blackshaw \& Salisbury, 1957) and there is disruption of the cell surface (Walton, 1957). It seems unlikely, however, that the effect of potassium during chilling at moderate rates is associated with permeability changes, since increasing the rate of chilling (which would be expected to increase cell membrane changes) did not change the reaction of the cell to the presence of potassium during chilling.

Since dialysed seminal plasma was as effective as non-dialysed, the beneficial effect of seminal plasma on washed ram spermatozoa during storage at $5^{\circ} \mathrm{C}$ was due to high molecular weight substances'such as proteins. Miscellaneous high molecular weight substances protect spermatozoa against the detrimental effects of excessive dilution and washing (Emmens \& Swyer, 1948; Blackshaw, 1953b; Wales \& White, 1961, 1963) and casein helps to protect ram and bull spermatozoa against cold shock (Choong \& Wales, 1962). These substances probably act by the physical action of preventing loss of intracellular materials such as potassium and magnesium. The protection afforded by seminal proteins during chilling may occur by a similar mechanism. The finding that low levels of potassium maintained the motility of washed and chilled ram spermatozoa during storage at $5^{\circ} \mathrm{C}$ would suggest that leaching of this cation during washing was one of the important factors in producing the depression during storage caused by washing.

\section{ACKNOWLEDGMENTS}

The authors are indebted to Professor C. W. Emmens for advice and help in this investigation. This work was aided by a Walter and Eliza Hall Research Fellowship (T. O'S.).

\section{REFERENCES}

Bzackshaw, A. W. (1953a) The effect of potassium and calcium salts on the motility of ram, rabbit and bull spermatozoa. 7. Physiol. 120, 465.

Blackshaw, A. W. (1953b) The motility of ram and bull spermatozoa in dilute suspension. 7. gen. Physiol. 36, 449.

Br.ackshaw, A. W. (1954) A bipolar rectal electrode for the electrical production of ejaculation in sheep. Aust. vet. 7. 30, 249.

Blackshaw, A. W. \& Salrsbury, G. W. (1957) Factors influencing metabolic activity of bull spermatozoa. II. Cold shock and its prevention. F. Dairy Sci. 40, 1099.

Choong, G. H. \& Wales, R. G. (1962) The effect of cold shock on spermatozoa. Aust. 7. biol. Sci. 15, 543.

Ghoong, C. H. \& Wales, R. G. (1963) The use of various diluents for deep freezing bull spermatozoa. Aust. 7. biol. Sci. 16, 896.

Emmens, C. W. (1947) The motility and viability of rabbit spermatozoa at different hydrogen ion concentrations. 7. Physiol. 106, 471.

Emmens, G. W. (1948) The effect of variations in osmotic pressure and electrolyte concentration on the motility of rabbit spermatozoa at different hydrogen ion concentrations. 7. Physiol. 107, 129.

Emmens, C. W. \& SwYer, G. I. M. (1948) Observations on the motility of rabbit spermatozoa in dilute suspension. F. gen. Physiol. 32, 121. 
KampschmDt, R. F., MEYer, D. T. \& Herman, H. A. (1953) Viability of bull spermatozoa as influenced by various sugars and electrolytes in the storage medium. Bull. Minn. agric. exp. Sta. No. 519.

LARDy, H. A. \& Phillips, P. H. (1943) Effect of $\mathrm{pH}$ and certain electrolytes on the metabolism of ejaculated spermatozoa. Amer. F. Physiol. 138, 741 .

Macleod, R. A. \& ONOFREY, E. (1954) Cation antagonism of the antibacterial action of amines. $\mathcal{F}$. biol. Chem. 210, 193.

Omachi, A., Macey, R. I. \& Waldeck, J. G. (1961) Permeability of cell membranes to amine buffers and their effects on electrolyte transport. Ann. N.Y. Acad. Sci. 92, 478.

SAlisbury, G. W. \& Lodge, J. R. (1962) Metabolism of spermatozoa. Advanc. Enzymol. 24, 35.

WALES, R. G. \& White, I. G. (1958a) The effect of the ions of the alkali metals magnesium and calcium on dog spermatozoa. F. Physiol. 142, 494.

WaLES, R. G. \& WhItE, I. G. (1958b) The effect of alkali metal, magnesium and calcium ions on the motility of fowl spermatozoa. Aust. F. biol. Sci. 11, 589 .

Wales, R. G. \& White, I. G. (1961) The viability of fowl spermatozoa in dilute suspension. Aust. $\mathcal{F}$. biol. Sci. 14, 637.

Wales, R. G. \& WhIte, I. G. (1963) The viability of diluted dog spermatozoa in vitro. F. Reprod. Fertil. 5, 67.

Walton, A. (1957) Cold shock of spermatozoa. Proc. roy. Soc. B, 147, 508.

White, I. G. (1953a) The effect of potassium on the washing and dilution of mammalian spermatozoa. Aust. F. exp. Biol. med. Sci. 31, 193.

White, I. G. (1953b) Metabolic studies of washed and diluted ram and bull spermatozoa. Aust. J. biol. Sci. 6, 706.

WhITE, I. G. (1953c) Studies on the alkali metal requirements of ram and bull spermatozoa. Aust. $\mathcal{F}$. biol. Sci. 6, 716. 